Article

\title{
Reading the Brussels Palimpsest in the History of the Nouveau Plan de Bruxelles Industriel (1910)
}

\author{
Marine Declève ${ }^{1,2}$ \\ ${ }^{1}$ EDAR-Architecture and Sciences of the City, EPFL-École polytechnique fédérale de Lausanne, 1015 Lausanne, \\ Switzerland; E-Mail: marine.decleve@epfl.ch \\ ${ }^{2}$ Metrolab Brussels, UCLouvain, 1060 Brussels, Belgium; E-Mail: m.decleve@metrolab.brussels
}

Submitted: 15 January 2020 | Accepted: 15 April 2020 | Published: 30 June 2020

\begin{abstract}
This article restores the dialogical link between the Nouveau Plan de Bruxelles Industriel avec ses Suburbains, published on the occasion of the 1910 Industrial Exhibition (Verwest, Vanderoost, \& Xhardez, 1910a), and the Inventaire Visuel de L'architecture Industrielle de L'agglomération de Bruxelles, produced by Maurice Culot and the team at the Archives d'Architecture Moderne (AAM) between 1980-1982 (Culot \& the AMM, 1980-1982). These two kinds of spatialised visual inventories of places dedicated to production brings out a layer of the Brussels palimpsest filled with information that goes beyond the categories of permanence, persistence and disappearance raised by André Corboz and Alain Leveillé's cartographic implementation of the palimpsest theory in the Atlas du Territoire Genevois (Corboz, 1993). This article compares palimpsest theory as applied to Geneva to the practice of inventory in Brussels. We propose visualising a lisuel layer intended as a visual reading revealed through a process of description, extraction, classification and juxtaposition. This process of visual analysis helps construct a typology of manufacturing production whose traces are embedded in urban space. It shows how a cartographic document informs the 1910 urban project and how local manufacturing companies contributed to its implementation. The contribution of this cartographic investigation is threefold. It concerns forms of manufacturing companies, forms of living, and production of urban space in 1910 Brussels. The Brussels Industrial Exhibition and the spatial story of Louis De Waele's public works company reveals two patterns of relationships between industrial production and the transformation of urban space.
\end{abstract}

\section{Keywords}

Brussels' industrial map; palimpsest-based urbanism; urban morphology; urban production

Issue

This article is part of the issue "Territories in Time: Mapping Palimpsest Horizons" edited by Chiara Cavalieri (UCLouvain, Belgium) and Elena Cogato Lanza (EPFL, Switzerland).

(C) 2020 by the author; licensee Cogitatio (Lisbon, Portugal). This article is licensed under a Creative Commons Attribution 4.0 International License (CC BY).

\section{Introduction}

The notion of territory as a palimpsest was formulated in Switzerland by André Corboz in 1983. He continued his reflection in a text written for the Atlas du Territoire Genevois (Corboz, 1993). In applying palimpsest theory to territory, the traces of the triple structure of road system, land parcels and buildings are interpreted according to three modalities: permanence (when traces are present faithfully), persistence (when they are perceptible but modified) and disappearance (when they no longer exist). In the atlas the reading of the palimpsest results from the superimposition of maps for studying Geneva's territory development from the Napoleonic cadastre in order to understand what remains or differs from 1806-1818. The aim of the atlas is not to engage in heritage protection of these traces, but rather to record changes in order to understand them and inform future development projects. In Belgium, at the same time and with the same concern for territorial knowledge, Maurice Culot and his team conducted the Inventaire Visuel de L'architecture Industrielle de L'agglomération de Bruxelles (henceforth, the Inventaire Visuel), an archival corpus of twenty two volumes (Culot 
\& the AMM, 1980-1982). In the same way that the goal of the atlas was to reveal new knowledge, the visual inventory compiled archives to make an inventory of the architecture linked to productive spaces, leaving open the question of the 'patrimonialisation' of the remaining traces.

Each volume of the Inventaire Visuel starts by referring to the Nouveau Plan de Bruxelles Industriel avec ses Suburbains (henceforth, the Plan Industriel; see Figure 1). The Plan Industriel is a historical cartographic document that bears witness to an urban production regime. It is an advertising document celebrating industrial architecture. Produced in the spatial and temporal context of 1910 Brussels, the document shows the spatial organisation, volume and location of about fifty companies involved in the city's industrial growth. It also shows the plan of the 1910 Brussels Industrial Exhibition on the Solbosch plateau in Ixelles (south-east Brussels).

In each volume of the Inventaire Visuel, a detail of the Plan Industriel emphasises the companies subjected

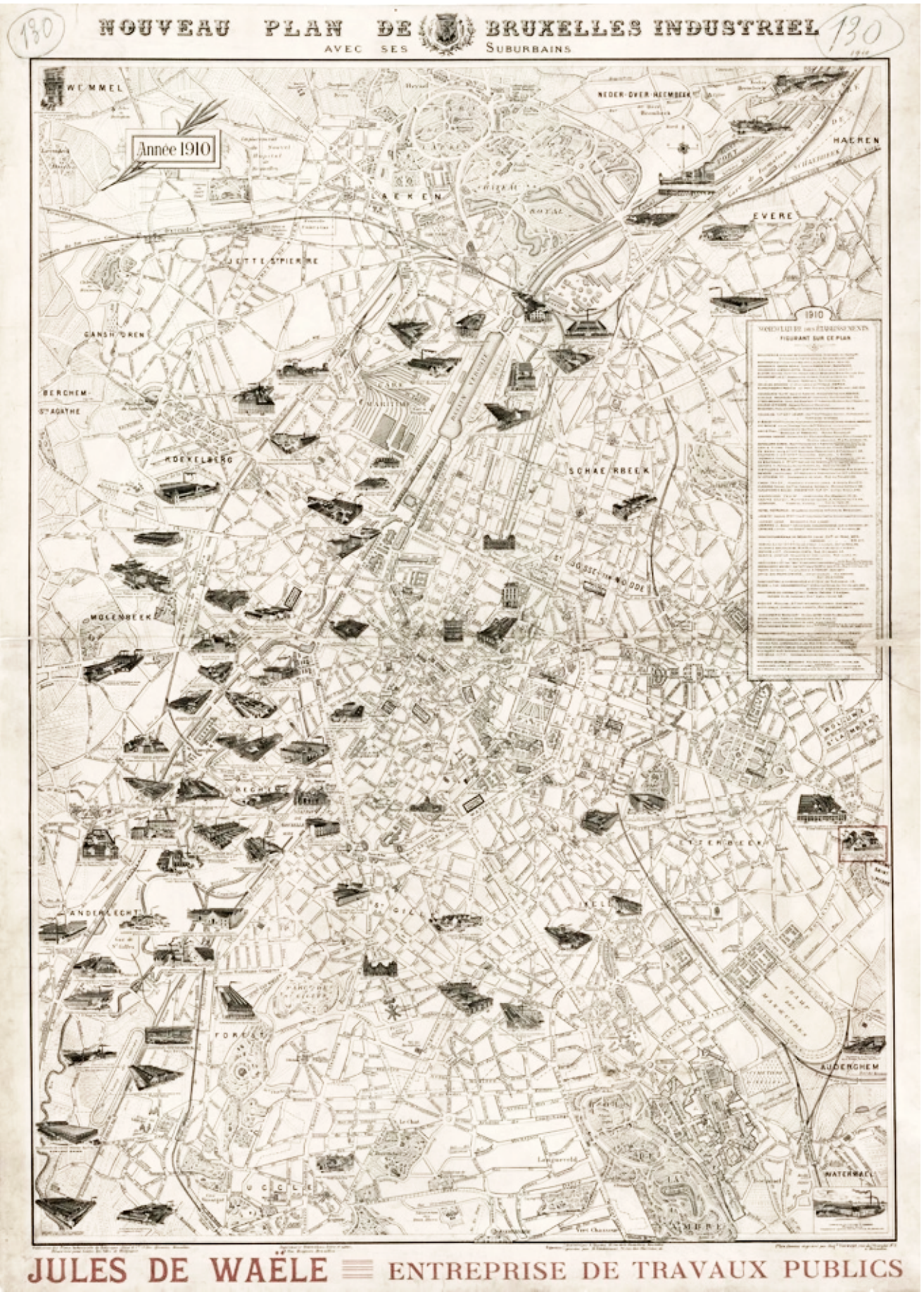

Figure 1. Plan Industriel (Verwest, Vanderoost, \& Xhardez, 1910a). Courtesy of the Archives de la Ville de Bruxelles (plan de Bruxelles no. 130, section cartographique). 
to further historical research (Figure 2). These companies are then incorporated in a map of all the industrial buildings recorded in the volume of the visual inventory. Numbers refer to fact sheets which describe the construction, development and uses of industrial buildings.

In this article, we explore the relationship between manufacturing companies and the city through a visual reading that creates an interaction between morphological palimpsest analysis and archives. The relationship between the Plan Industriel and the Inventaire Visuel is dialogical. The palimpsest layer we intend to reveal is encompassed within the diachronic reading of these two documents which serve as a basis for a cartographic investigation. Starting with the description and history of the two documents, the investigation engages in a reading process which ends in a visual analysis aimed at going beyond the categories of permanence, persistence and disappearance raised by Corboz (1993). The neologism lisuel, which we use to refer to this visual reading, has been theorised by Gullentops (2001) regarding Jean Cocteau's poetry. In order not to lose this reference in translation, we kept the French neologism. Lisuel is a French contraction of what is both readable (lisible) and visual (visuel). This neologism is transposed to this cartographic investigation to free the palimpsest from a literal stratigraphic reading. Making several possibilities of reading and interpretation co-exist through a process of extraction, classification and juxtaposition, it forms a thought pattern which questions the roles of archives in urban production (Rao, 2009; Van Damme, 2012), of urban imagery (Pousin, 2005; Söderström, 2000) and of spatial analysis (Arnaud, 2008).

For Brussels, the archives compiled in the visual inventory are specific and depicted the relationship be- tween industrial production and the transformation of urban space. As the latter dealt with the economic regime and forms of manufacturing companies, it fuels our cartographic investigation with material and spatial but also immaterial and socio-economic elements. The spatial stories of the industrial companies represented in the Plan Industriel configure the systems of relationships between the manufacturing companies and the city. In this article, we take the history of general public works contractor Louis De Waele, a family business founded in 1866 by De Waele and his brother Jean as a carpentry and woodworking company, as a case to illustrate our visual reading of this system of relationships. This specific family business has been chosen because of its important role in both the physical transformation of the urban space and the promotion of the Plan Industriel.

Indeed, as mentioned at the bottom of the Plan Industriel, Jules De Waele-one of the four sons of Louis De Waele, who took over the family business when the latter died in 1900-sponsored the drawing's publication. This led the authors of the Inventaire Visuel to call it the "plan De Waele". In the fact sheet on Jules De Waele's company, the authors state:

In 1910, Jules De Waele took the initiative to publish a map of Brussels in which his enterprise is listed alongside the establishments most representative of the industrial boom at the beginning of this century: the Nouveau Plan de Bruxelles Industriel avec ses Surburbains. This initiative is undoubtedly commensurate with the importance that this enterprise had acquired when it moved into its premises on Saint-Hubert Street. (Culot \& the AMM, 1980-1982; author's translation)
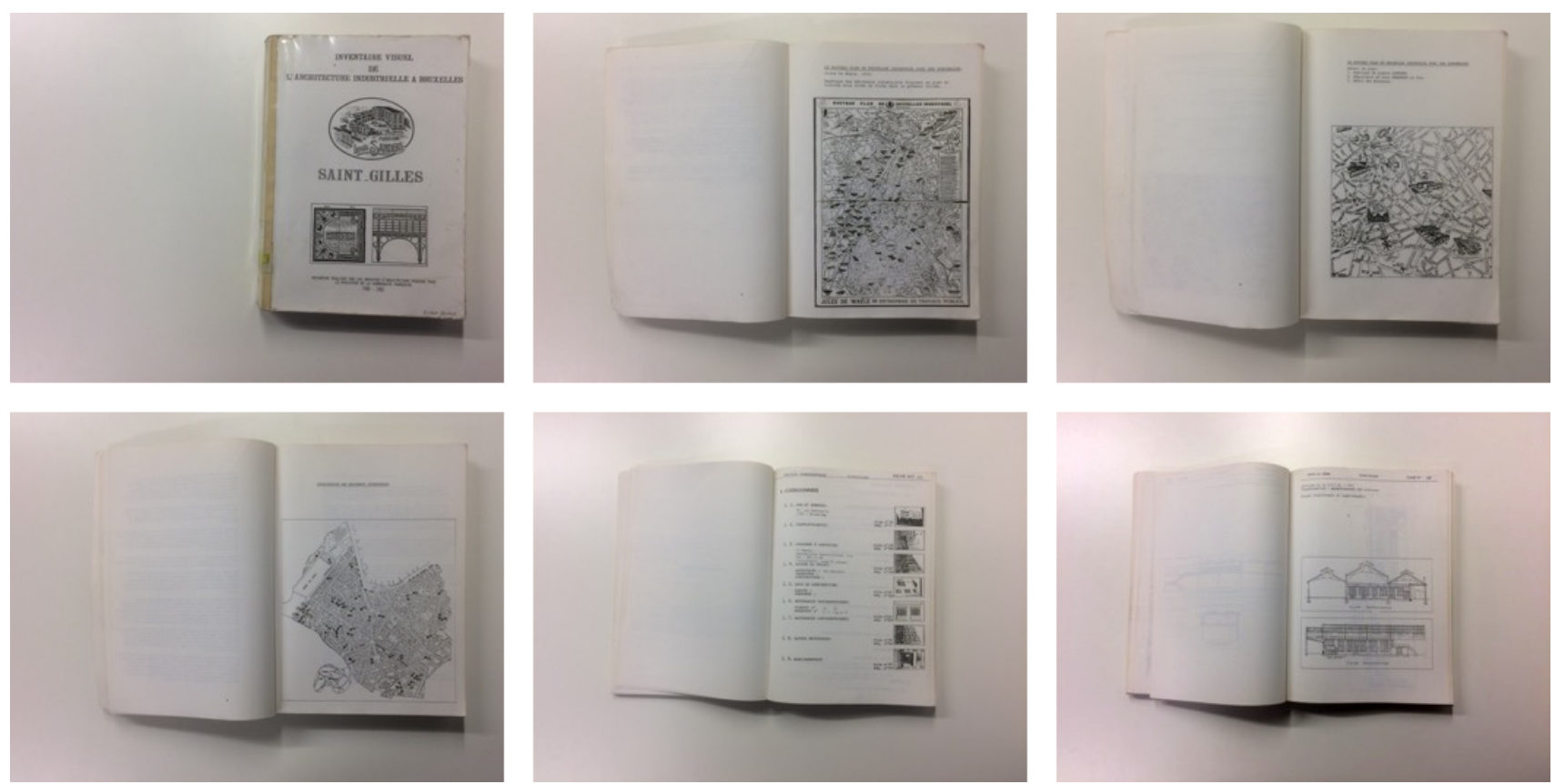

Figure 2. Inventaire Visuel. From the Bibliothèque Générale des Sciences Humaines (BGSH, UCLouvain). Photograph by the author. 
The idea spread that the initiative to publish the plan was taken by De Waele. Nevertheless, different versions of the plan can be found in the archives. So far, we have found three: one advertising Jules de Waele's company, in the Brussels City Archives, one advertising the Virginal paper mills, in Ghent University Library (online collection), and one advertising Désiré Flamand's paving and asphalt company, in the National Library of Belgium (online collection). As in the 1980 s the Plan Industriel recurred throughout the Inventaire Visuel; it reappeared also in 2014 to serve the vision of Brussels as a productive city. This recent resurgence motivates us to determine how it contributes to the understanding of the Brussels palimpsest.

\section{Belgian Industrial Plans}

The Plan Industriel was drawn up by a consortium of graphic industries on the occasion of the 1910 Brussels
World's Fair. It initiated a series of similar maps for the cities of Charleroi (dated 1911), Liège (dated 1911), Ghent (dated 1912), Antwerp (dated 1914), and Verviers (dated 1914). These maps offer for each city a nomenclature or directory of industrial establishments which includes in a non-systematic way the company name, building type (workshop, office, warehouse) and address. The maps show the contemporary facades or buildings as etched vignettes without taking into consideration their orientation or scale. A red box highlights the company financing the plan's drafting or printing. The same colour is used for the description of its business, in the lower part of the print. These documents are not plans in the sense of urban planning. At the time when these advertising documents were published, the development of Brussels was governed by a process of "dotted-line planning" (Zitouni, 2010), the most eloquent expression of which was the Besme plan (Figure 3), named after the head of the provincial roads department which guided

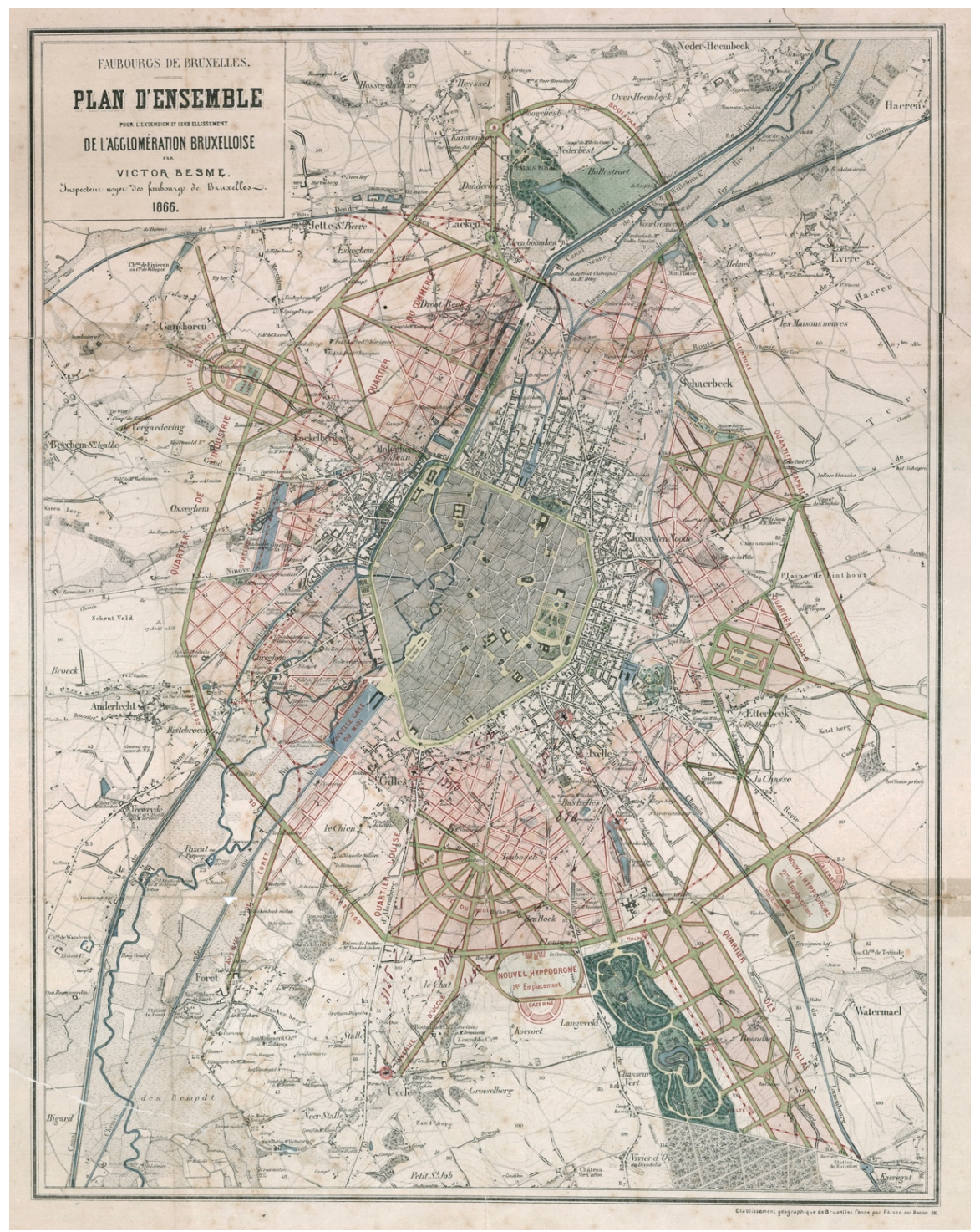

Figure 3. Plan D'ensemble pour L'extension et L'embellissement de L'agglomération Bruxelloise (Besme, 1866). Courtesy of the Archives de la Ville de Bruxelles (plan de Bruxelles no. 96/8, section cartographique). 
the extension of the city beyond its walls, prefiguring what would today probably be called negotiated urban planning. The Besme plan was first drawn up in 1863 and redesigned in 1868 (De Beule, 2017). The industrial maps are cartographic documents with no projective or scientific aim. Nevertheless, they constitute a solid basis for a spatialised inventory of the productive activities contributing to the development of these cities. In the case of Brussels, it also showcases the latest city transformations linked to the implementation of the Besme plan.

The comparison with the 1910 Brussels official cartographic institute (IGN) map shows the plan's uniqueness. Indeed, one feature that distinguishes the Brussels map from the others of the series and from contemporary maps such as IGN's is that it shows the urban design of the 1910 Brussels World's Fair on the Solbosch plateau in Ixelles (Figure 4). During that era, several Belgian cities organised international exhibitions. World's fairs, however, like the one in Brussels in 1910, were defined as industrial, universal and international exhibitions when they assessed "the means and progress made or to be made in several branches of human activity" (Schroeder-Gudehus \& Rasmussen, 1992). While the first two maps in the series, of Brussels (dated 1910) and Charleroi (dated 1911), were produced during a world's fair year, the latter does not include the fair's urban design and only mentions its location. This gives the map of Brussels new value since it is one of the few documents showing the essential impact of an event dedicated to science, arts, industry and commerce, and lasting a few weeks, on the city's urbanisation over the long term.

Urban production related to the 1910 World's Fair is quite specific, as it was designed by the World's Fair Company responsible for the urban development related to the event. This company had its own head architect (Gédéon Bordiau, assisted by Ernest Acker and Louis Van der Swaelmen) and chief engineer (Alfred Masion). The impact of the fair has two relevant aspects regarding urban production. The first is the urban development of
Brussels, particularly the extension of the city towards Ixelles. The second is how the fair reveals the emerging concept of social economy. This aspect reflects the adoption of the law on workers' housing, which foreshadows the next episode in the history of Brussels's development and links it to Victor Besme's considerations of workers' housing support.

The story of the Plan Industriel is a reiteration that a cartographic document, like a territory, is a construction which is a process, product and project (Corboz, 1983), in this case related to a major event for the city. This plan represents spaces of which the industrial city can boast. In addition to private companies, facilities, and public spaces, it also includes gardens and parks that were linked at the time to hygienic requirements. The plan displays the pride a city can take in its industry and celebrates national prosperity. It envisions a city that claims its capacity for innovation and progress but also the knowhow and technique of its craftsmen. It shows the city's transformation to accommodate industry, workers' housing estates, schools, and hospitals, but also emphasises rail and transport as city transformations that allow local manufacturing companies to function and, in doing so, promote a specific image and economy of the city.

These maps became eloquent witnesses to the spatial organisation of industry at the turn of the 20th century. The series began with the Brussels map as an official publication of the Plans Industriels de Belgique. This map was edited by Khiat and printed by Gouweloos. The base map was drawn and engraved by Auguste Verwest, while the vignettes were drawn by Fernand Xhardez and engraved by Marcel Vanderoost. The same consortium of graphic industries was responsible for the Nouveau Plan de Bruxelles Mondain from 1910 (Figure 5), its directory of commercial and elegant establishments in the centre of the capital (Danckaert, 1989), and World's Fair brochures and tourist maps (Figure 6) that show the tramway lines built to reach the fair site in Ixelles (Jaumain, 2010).
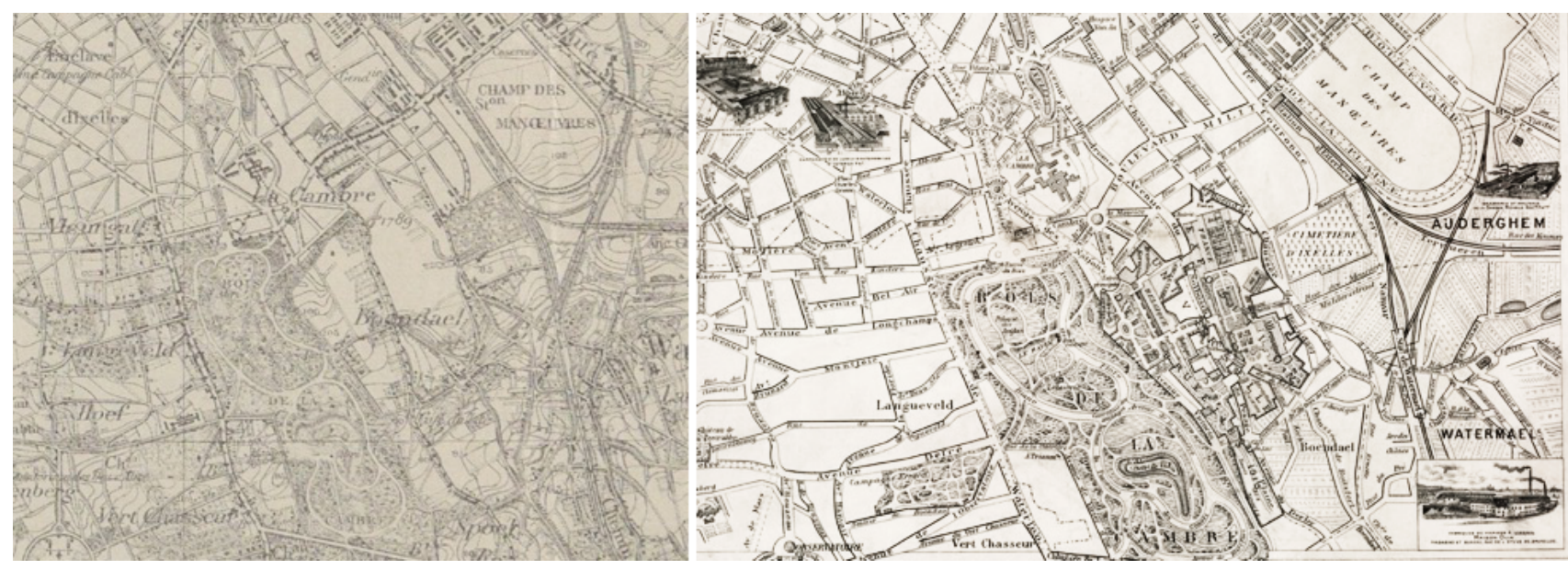

Figure 4. Detail of the Solbosch plateau, site of the 1910 Brussels World's Fair (IGN, 1910; Verwest et al., 1910a). Courtesy of the Ghent University Library and of the Archives de la Ville de Bruxelles (plan de Bruxelles no. 130, section cartographique). 


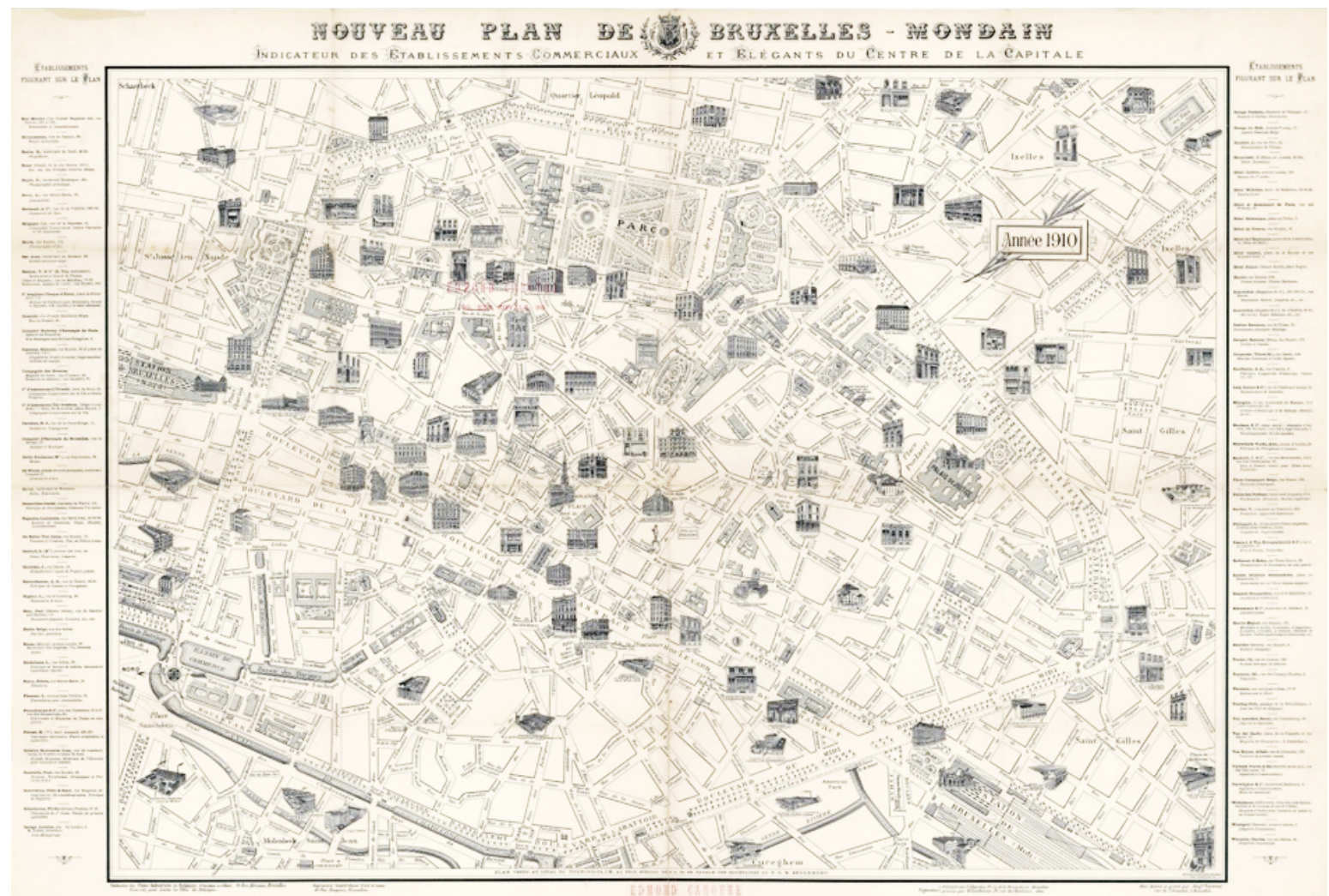

Figure 5. Nouveau Plan de Bruxelles Mondain (Verwest et al., 1910b). Courtesy of the Musée royal de l'Armée (cartes, Bruxelles 60).

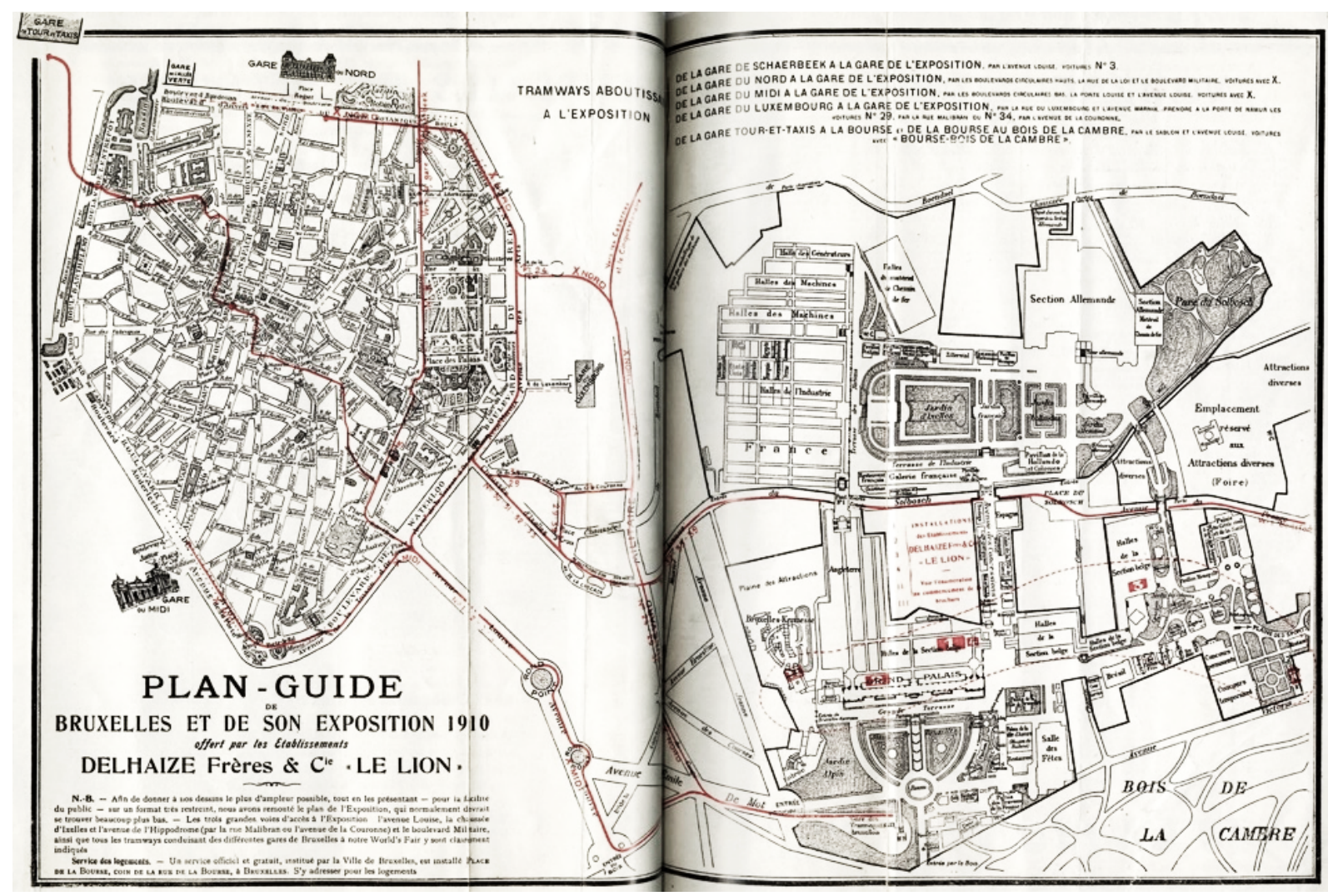

Figure 6. The World's Fair and the redevelopment of the tramways (Jaumain, 2010, pp. 88-89). 


\section{The Visual Inventory of the Industrial Architecture of the Brussels Agglomeration}

Culot's Inventaire Visuel of 1980-1982 covers the territory of the nineteen municipalities of what was then called the Brussels Agglomeration. This agglomeration took shape in 1971. It was revised in the 1980s when the regionalisation agreements were negotiated, leading first to the creation of the Walloon and Flemish regions and then, in 1989, the Brussels-Capital Region.

The inventory's aim was to integrate knowledge of industrial heritage into the toolbox of the city's economic redevelopment, at a time when the modernist frenzy was condemning secondary economic activities to the benefit of the tertiary sector (and hygienist zoning) and conceived urban renewal only through the filter of a tabula rasa. In Brussels, the phenomenon of the city's radical transformation earned the name "bruxellisation" (Schoonbrodt, 2007). The project to conduct this Inventaire Visuel followed the emergency pre-inventory published and carried out in 1975 by the non-profit organisation Sint-Lukasarchief (Région de Bruxelles-Capitale, 2019). To complete this pre-inventory the Ministry of the French Community commissioned thematic inventories of, for example, industrial architecture and social housing, or maisons du peuple. These inventories were conceived as knowledge tools to provide an overall view of the agglomeration's significant specificities in terms of architecture and urban history. Today they have been integrated into the Inventaire $d u$ Patrimoine Architectural (Région de Bruxelles-Capitale, 2019) and are a prerequisite for adopting conservation and protection policies.

The volumes are organised by municipality. The introductory text to each volume details the municipality's industrial profile and describes the variety of urban landscapes, which are classified into three types: residential, working class, and industrial.

The Inventaire Visuel included fact sheets aimed at restoring the architecture of one hundred industrial buildings still present in 1980. Selected buildings had to have been constructed before 1940 and be representative of industrial or manufacturing building types. Other selection criteria ranged from pure architectural quality to the building's impact on the urban morphology. Fact sheets were classified according to the original use of each building. Each fact sheet addresses a single building and summarises identifying and builder information. It characterises the type of industry for which the building was built, details its successive uses, describes its architectural character and the urban context in which it is located. The buildings were identified on the basis of field surveys, archive research, cadastral extracts, and aerial photograph analysis. Fact sheets also detail, in an appendix, the archives' classification system.

Each fact sheet's appendix also contains a compilation of archival documents collected at that time. These appendices show a diverse range of archival doc- uments such as plans and building permits, official letters, company advertisements, and newspaper articles. While the fact sheets focus on categorising the buildings, the archival documents provide information on the relationship between industrial companies and their urban context, unveiling the economic regime underlying the city's development.

\section{Lisuel Layer of the Palimpsest}

Beyond the modalities of permanence, subsistence, and transformation depicted by Corboz (1993) for the study of the development of land parcels, buildings, and roads, the study of the uses and their evolution through spaces allow for reconfiguring the conditions in which traces passed from one category to another. The effort made by Culot and the AAM to carry out the visual inventory was driven by the desire to document the stories behind the traces. The inventory managed to complete the picture of the De Waele plan and enrich it with the specific histories of the companies. These particular histories reveal the relationship that exists between a territory, its architecture, and the diachronic lifestyles which it hosts.

The lisuel layer of the palimpsest we propose is a visual reading of these histories behind the traces. It ties them to political, social, and cultural changes. Our visual reading was a process of extraction (showing the featured situations), classification (setting up a typology), and juxtaposition of archives (engaging the visual analysis). Extraction depicted featured situations on a base map to establish the architecture of the city from a specific document; classification, by cross-checking another document, helped organise these features under a theme linked to urban production chains; juxtaposition of archives reveals the impact of a manufacturing company in the transformation of urban space.

\subsection{Extraction}

Extraction is a delayering of the featured situations represented on the Plan Industriel (Figure 7). Although there is no legend, the map of Brussels delivers several levels of information. First are municipal boundaries. This may seem anecdotal, but when the plan was being drawn up, the communes were not merged under a common trusteeship and the extension of the territory of Brussels gave rise to intense conflicts. The framework of the Plan Industriel is centred on Brussels City, but companies appear also in surrounding municipalities despite the extension of Brussels City urbanising agricultural land. One of the etched vignettes even concerns paper mills located in Virginal (Wallonia). Regarding water and land transport, we can distinguish the canal and its basins, paved roads, paths, and plant-lined avenues. Also, the plan mentions squares and street names. Some of the streets' lines are dotted, testifying to the process of dotted-line planning which accompanied the extension of Brussels during the industrial era (Zitouni, 2010). Regarding rail- 


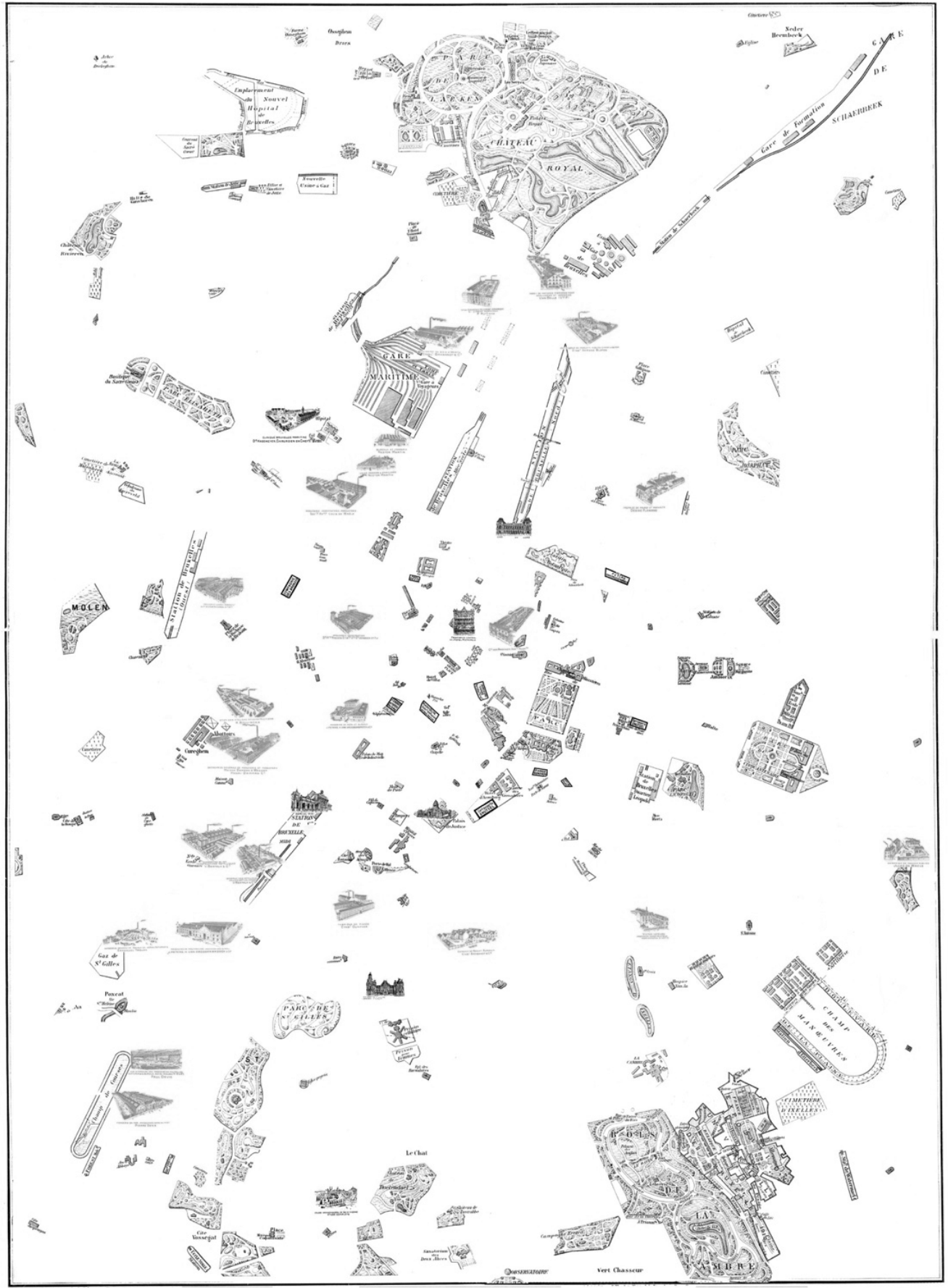

Figure 7. Extraction from the Plan Industriel (Verwest et al., 1910a, extraction made by the author). Courtesy of the Archives de la Ville de Bruxelles (plan de Bruxelles no. 130, section cartographique).

roads, the map of Brussels differs from those of other cities in that it does not differentiate passenger, industrial, local, and tram rail. Indeed, the legends of Antwerp, Ghent, Charleroi, Verviers and Liège city maps differentiate paved roads, paths, and passenger railways, local railways, industrial railways, and electric tram lines. This difference may be meaningless, but it does indicate the adherence of the collective transport networks to Brussels territory, notably through the extension of the network of local tramways. Regarding open spaces, one can see on the map of Brussels woods, fields, parks, and cemeter- ies. The drawings of the parks are as accurate as those of the vignettes. Finally, regarding infrastructure, the map shows churches, communal houses, barracks, farms, gasworks, convents and abbeys, castles, workers' housing estates, train stations, mills, fountains, hospitals, palaces, the observatory, slaughterhouses, the stock exchange, theatres, and covered passages. This delayering informs the analysis of the forms of living, in a city in which manufacturing companies took part as builders of the urban project envisioned by the Besme plan and supported by King Leopold II. 
With regard to Corboz's theory of territory as palimpsest, the process of extracting featured situations concerns mainly territorial apparitions which are superimposed on the initial palimpsest. This is the spatial expression of a new narrative rather than the expression of the 'old soil grimoire' on which it is based.

\subsection{Classification}

The purpose of classification is to establish a typology for highlighting a specific thematic layer. In the Inventaire Visuel the fact sheets are classified by the industrial category to which the building is related. These categories refer to the original use of the building related to the company's production (tobacco, sugar, cars, printing, etc.). Other categories appear in relation to building types (shops, warehouses, factories, workshops, etc.). The category 'workshops and buildings of unidentified (original) use' applies to small-scale buildings which host craft activities. The categories 'reconversions' (distinguishing in particular reconversions from a non-industrial to an industrial function, from an industrial to a commercial function, from an industrial to a cultural function) and 'disappeared buildings' refer to transformations. The classification system of the fact sheets therefore gathers building types (workshops, warehouses, dwellings, shops, etc.), uses (enamelling, printing, cigarette manufacturing, etc.) and conservation statuses (preserved building and use, demolished building, reconverted use). Classification by conservation status considers the resilience of industrial architecture.

The collage of the industrial buildings' location (Figure 8) retrieved from maps in each of the twenty-two volumes of the Inventaire Visuel reveals a regional geography. It shows geographical location factors, the logic of clustering by production sectors, and how these clusters determined the specialisation patterns of neighbourhoods in 1910. It highlights the two main dynamics of development of the Brussels economic urban fabric during the industrial era: the importance of the manufacturing axis in the valley occupied by the Senne-Canal system and the railways, and the proliferation of more arti-

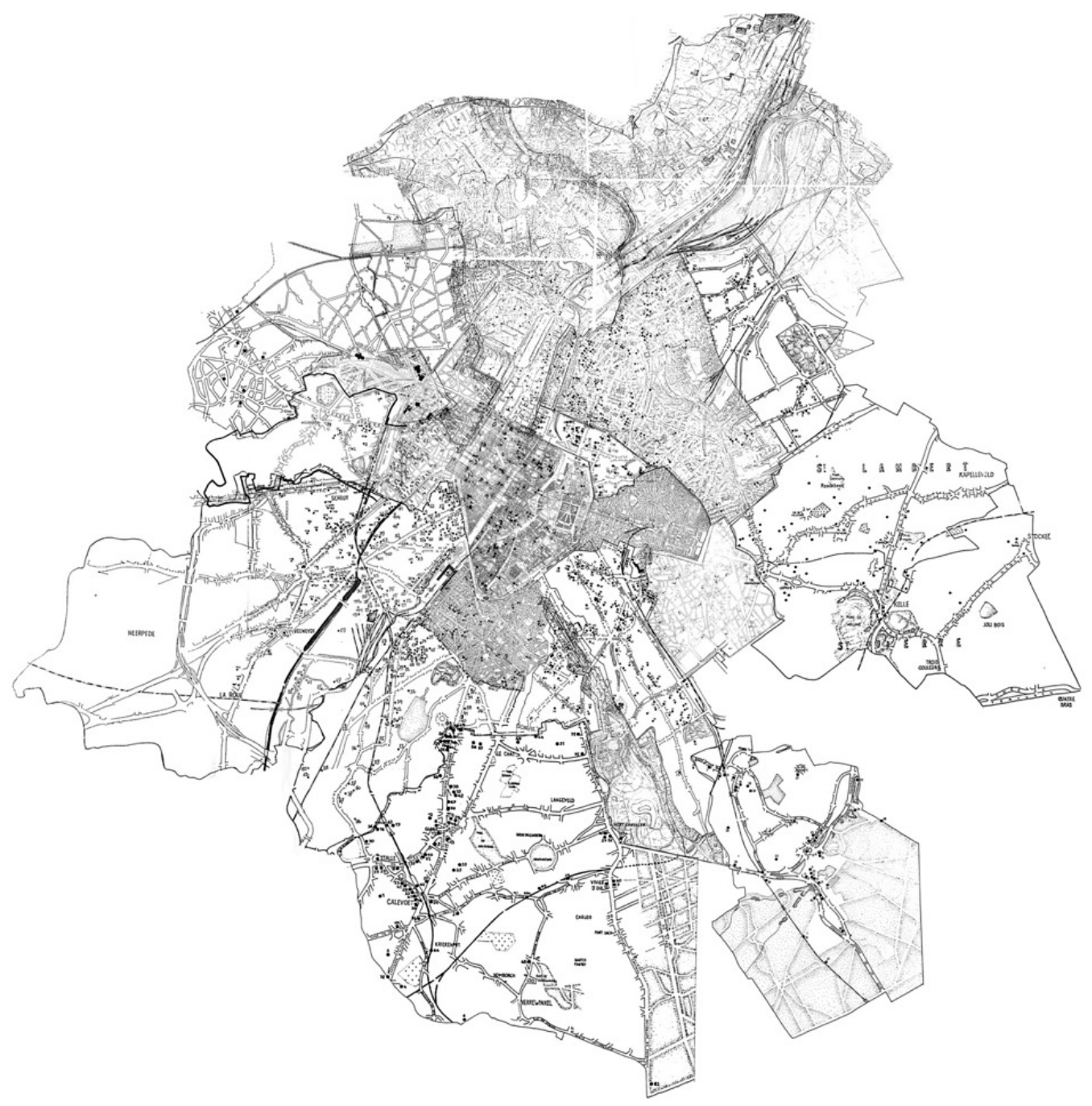

Figure 8. Location and classification of industrial buildings from the Inventaire Visuel (Culot \& the AMM, 1980-1982, Vols. 1-22; collage made by the author). 
sanal companies along the tributaries of the Senne River in old rural villages and newly urbanised districts (Atelier de Recherche et d'Action Urbaine, 1984). It also helps to investigate relationships of competition, complementarity, or convergence between companies operating in the same part of the territory at the same time.

The manufacturing axis consists of several subgroups. To the south, in Anderlecht, were textile factories (wax cloth, dyeing, cotton weaving). To the north, in Cureghem, the slaughterhouse engendered meat and leather industries (leather goods, shoe manufacturing). Breweries, flour mills, and tobacco factories settled in Molenbeek, on the opposite side of the canal from Brussels. In Ixelles, the integration of economic activities into the residential fabric shows a concentration of craft activities more directly related to domestic services (wood craftsmen, musical instruments, furniture, ironwork). To the south-east, in Boitsfort and Auderghem, the Sonian Forest spawned breweries and forestry activities. Businesses involved in the production of habitat and public space are scattered. This geography of activities can be found today in the toponymy of streets and extended by researching commerce and industry almanacs (available for the period 1820-1969).

Going back to the Plan Industriel, we distinguish seven themes to classify featured situations related to specific urban production chains: domestic infrastructure (public equipment such as train stations, court halls), imagery production (publishing activities such as printing, engraving, newspapers, etc.), food production (agricultural fields, beer, grains, etc.), household goods manufacturing (textiles, musical instruments, etc.), residential services (landlord offices, laundry, hotels, shops, waste collection, etc.), energy production (petrol, gas, etc.), and habitat and public space production (public works companies, wood and metal processing, building sites, etc.). This last group is the one we highlight for this visual analysis. It enables us to address both construction sector businesses and smaller-scale craft workshops. This classification informs the analysis of the forms of living to which each business contributes.

\subsection{Juxtaposition}

The featured situations extracted from the Plan Industriel and the cross-checking with archival documents extracted from the Inventaire Visuel reveal two patterns of relationships between industrial companies and the transformation of the urban space. The juxtaposition of the different categories of archives offered by the two documents helps visualise the urban production related to each company. We focus on analysing the spatial history of Louis De Waele's company, because it is part of the habitat and public space production theme of featured situations and relevant to the publication of the Plan Industriel. We begin with the extraction of the etched vignettes representing its two factories and proceed to locations associated with the production chain (workshops, warehouses, houses, offices, shops, construction sites).

Louis De Waele's spatial management has been studied in depth recently by Degraeve, Dobbels, Bertels, Deneweth, and Van De Voorde (2018). Nevertheless, the visualisation of its footprint on the Brussels palimpsest, showing the company's successive establishments within the city and its construction sites up to 1910 (Figure 9), has been retrieved here from the reading of the appendix of archives collected in the Inventaire Visuel.

The relationship between the company and the transformation of the urban space is based on two aspects. The first is the company's footprint and development of establishments within the city. Successive establishments of De Waele family companies during 1867-1927 can be deduced from four archival documents in the fact sheet appendix. The first is a very complete article written by Eugene Dhuicque and published in L'Emulation in 1927. Dhuicque (1927) locates company sites and describes the development of the family business. This description helps us understand the link between the two etched vignettes extracted from the Plan Industriel. The three other archival documents are plans: a building permit introduced in 1885 to build up a hangar on rue Ribaucourt (see Figure 9, aerial map, B), a request for a permit in 1912 for the Grand Atelier on Lavallée street 23-25 (see Figure 9, aerial map, C), and another request for a permit in 1921 for the extension of a factory on Léopold II boulevard 22-46 (see Figure 9, aerial map, D). These documents are set in an aerial photograph of Brussels which dates back to 1930 to visualise how Louis De Waele contributed to the urbanisation of the industrial neighbourhood of Molenbeek as envisioned by Victor Besme at the end of the 19th century (Figure 9).

By extrapolating from the fact sheet appendix, the spatial story of Louis De Waele's company can now be told. Its first workshops were established on the Quai aux Pierres de Taille. In 1867, carpentry and parquetry workshops moved to the l'Intendant street in Molenbeek. They were then transferred in 1888 to Lavallée street, in a vast building whose plans were drawn up by Henry Beyaert. At the time, the factory was electrified by its own means. In 1889, the company set up its offices and warehouses on boulevard Leopold II. In 1890, the architect Janlet drew up the plans for Louis De Waele's residential house (used later for administrative services), which was built alongside the boulevard. The building extensions of 1921-1922, per the plans of the architect Dhuicque, provide information regarding the firm's continuous development. At the turn of the 20th century, Louis de Waele's company became a very powerful general construction and public works company in Brussels, owing to Louis De Waele becoming the royal family's official contractor. The name of Louis De Waele evokes a period of construction in Belgium when the efforts of a series of craftsmen were combined to modernise the building trades: 


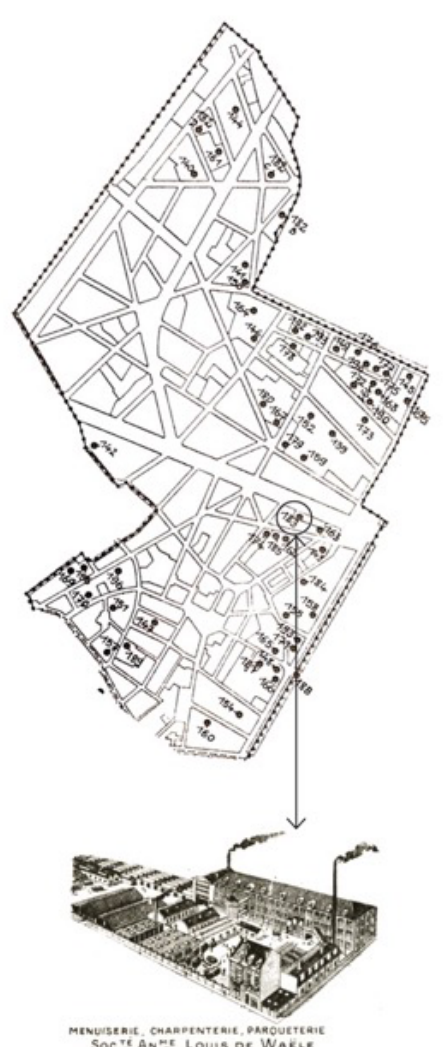

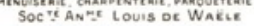
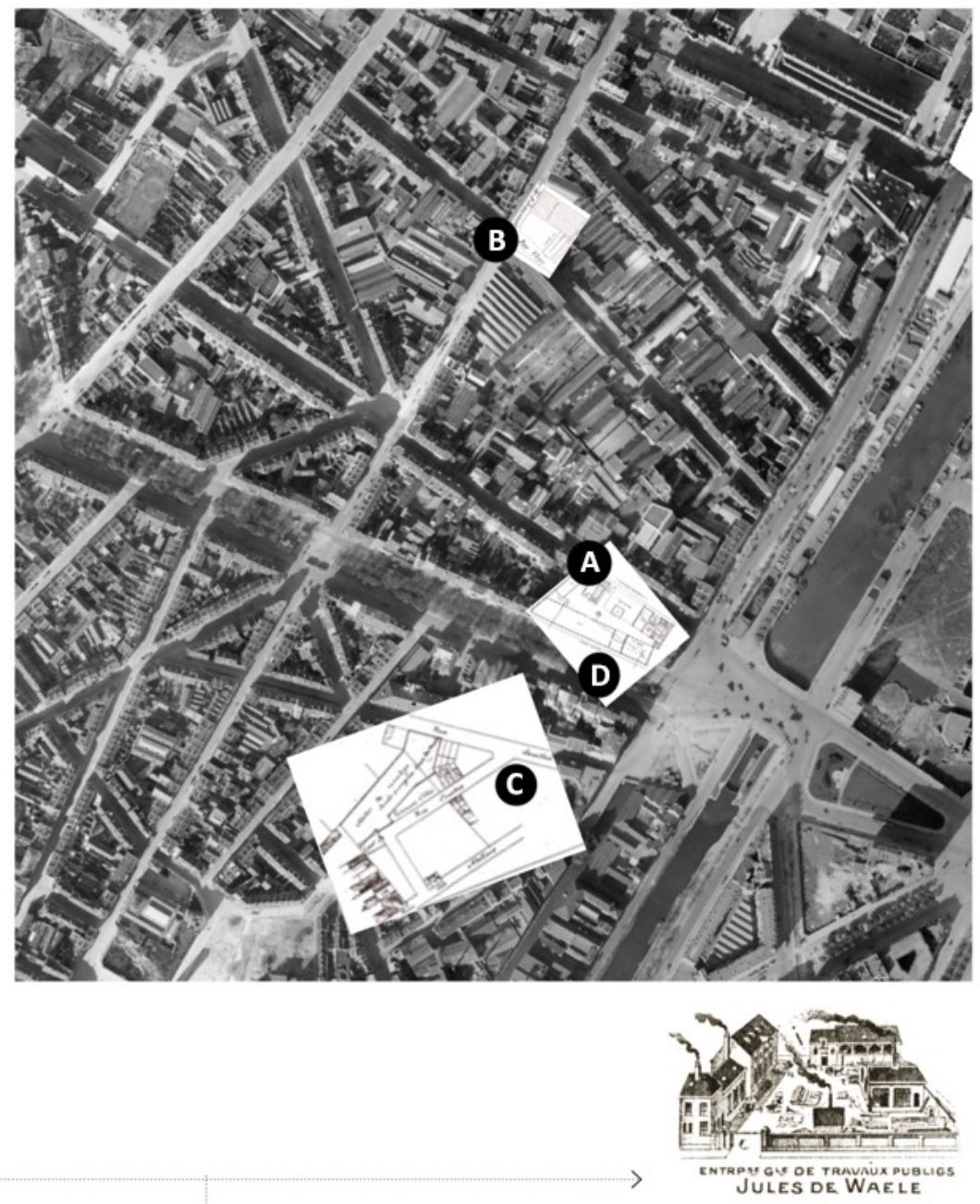

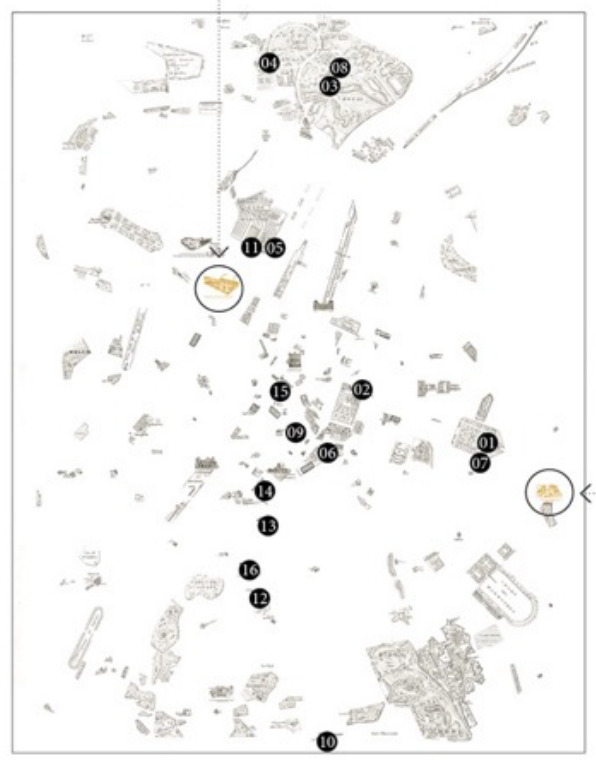

Figure 9. Lisuel layer of the palimpsest. Juxtaposition of archival documents (juxtaposition made by the author). From left to right: location of industrial buildings in Molenbeek (Culot \& the AAM, 1980-1982, Vol. 2); aerial photograph mission Brussels 1930-1935 (BUP-CIRB); building permits (Culot \& the AMM, 1980-1982, Vol. 2); advertisement for Louis De Waele's company (Culot \& the AMM, 1980-1982, Vol. 3); etched vignettes (Verwest et al., 1910a). 
Among the carpenters, cabinetmakers and parquet floorers was Joseph Godefroy, to whom the city of Brussels later owed the foundation of its school of carpentry; they were Henri Pelseneer and Louis De Waele, and shortly afterwards Edouard François; among the decorators, Gustave Janlet and then Henry Base; among the blacksmiths, Pierre Desmedt; among the plumbers, Gustave Pierre and Verhoogen; among the ornamentalists, Georges Houtstont and many others. (Dhuicque, 1927, as cited in Culot \& the AMM, 1980-1982; author's translation)

The know-how and expertise of Louis De Waele's company was celebrated at the exhibitions of Antwerp (18881894, Grand Prix), Amsterdam (1883, Gold Medal) and Scheveningen (in 1892), among others. The firm was incorporated in 1902 as a limited company. After Louis's death in 1900, management was entrusted jointly to his four sons, Albert, Gaston, Oscar, and Jules. Subsequently, another Louis (Gaston's son) ran the business until 1982. After 1982, Louis-Marc (Gaston's grandson) and his cousin Jean-Thomas (Albert's grandson) took over the family business. In 1927, its factory employed no fewer than 450 workers, while its building sites employed 500 workers.

The second aspect of the company's relationship to urban space transformation is its locating its construction sites within the city. Retrieved from the fact sheet appendix in the Inventaire Visuel, an advertisement for Louis De Waele lists some of the works it carried out at that time. Sixteen sites can be located as featured situations extracted from the Plan Industriel: the national exhibition of the Jubelpark (plans by Bordiau in 1880), the reconstructed National Palace (plans by Beyaert, burnt down in 1883), the reconstructed Royal Palace of Laeken (plans by Balat, burnt down in 1894), the Royal Farm of Stuyvenbergh in Laeken (plans by Janlet), the new warehouses in Brussels (plans by Van Humbeek), the barracks in des Petits Carmes street (plans by Van Ysendyck), the galleries adjoining the Jubelpark arcade (plans by Girault), the extension of the Royal Palace in Laeken (plans by Girault), the joinery and parquet flooring of the Royal Palace in Brussels, the Royal Observatory, the post and railway stations, Saint-Gilles prison, the Hotel des Monnaies, Saint-Jean and Saint-Pierre hospitals, the public prosecutor's offices in the town halls of Brussels and Saint-Gilles, and the General Society for the Promotion of Industry.

This advertisement also contained four views of the showroom, of a wood store, of the workshops and of the engine rooms.

The representation of this juxtaposition is a graphic indication of the impact of these establishments and their activities on Brussels morphology in which the production of urban space is seen both as the product of the work of local manufacturing companies and as space induced by their presence and forms.

Forms of manufacturing companies are influenced by both the production chain (referring to machinery and work organisation) and type of entrepreneurship. On the Plan Industriel, the very detailed etched vignettes reveal microcosms. These are groups of buildings in which a whole production chain is taking place. As local companies were building the city and shaping its image, urban space became the showcase for exhibiting the knowhow of Brussels entrepreneurs. The particular case of De Waele shows the destiny of a flourishing company that has grown so much that it is now global. Other companies may have left their traces but disappeared, while still others were able to continue their activity on a small scale. The forms of manufacturing companies have to consider the types of entrepreneurship, such as the four characterised by Cooney in 1955 and described in Bertels, Deneweth, Horemans, and Van De Voorde (2016): the self-employed master craftsman, the master craftsman responsible for all construction, the builder, and the master builder. This discerns all-inclusive manufacturing companies from fragmented manufacturing companies or associated manufacturing companies and considers their scales as they adapt to the urban environment. Understanding the evolution in the forms of manufacturing companies also requires considering historical aspects such as the development of the Arts and Crafts Movement in England (from the 1880s) or Art Nouveau in Brussels (from 1890) and the systematisation of the scientific organisation of work by Frederick Taylor (1911), who set out his method in The Principles of Scientific Management.

Other elements of the Plan Industriel serve to identify forms of living, which resulted in part from the conditions in which workplaces were laid out in relation to residences and places of public life. The Plan Industriel says little about how the relationship between workplaces and residences was defined in 1910. However, it does provide some significant clues. In the case of Louis De Waele's company, for instance, the house occupied by the contractor until his death in 1900 is drawn since it was integrated into the factory. The plan also mentions the existence of workers' housing estates (Cité Fontainas, Cité Jacquemyns), which testifies to the value that was placed on the production of affordable housing already supported by Victor Besme in 1868 but which truly took off in Brussels with the rise of garden cities from 1915 to 1930. Concerning places of public life, the plan focuses on train stations, hotels, and covered passages. Other contemporary documents such as the Nouveau Plan de Bruxelles Mondain (on which Louis De Waele's company is depicted as a joiner's workshop) or the Delhaize advertisement show landmarks of a sociability specifically linked to work (shops, department stores, luxury craft factories, markets, galleries, hotels, museums, and theatres) but also schools (including the vocational school of joinery and the industrial school) and the maison du peuple. Some of these facilities are financed either by companies (which already use the term 'social economy'), workers' cooperatives, or trade union organisations. 


\section{Conclusion}

In the end, after a journey through an investigation which began with a cartographic document, what does the lisuel layer bring to the palimpsest theory? In this article, we contextualised the contribution of Corboz (1993) relative to the palimpsest theory and the methodology of the visual inventory exercised during the same period by Culot and his team. While they share the goal of revealing territorial knowledge to inform future development projects, their outputs differ. Corboz and Leveillé's superposition of maps to record changes in the evolution of land parcels resulted in cartographic documents. These cartographic documents revealed modalities of permanence, subsistence, and transformation. Culot and his team's inventory work recorded the changes in building use and associated each building with a compilation of archives. Inventory practice allowed for reconfiguring the conditions in which traces passed from one modality to another.

The methodology of building up the palimpsest's lisuel layer consists in connecting these different categories of archives. It combines the interpretation of a cartographic document with that of the visual inventory. It attempts to visualise the role played by archives in urban production, their uses, and the connection between different kinds of archives. Instead of arguing for a stratigraphic reading, the lisuel layer aimed at visualising a 'thickness' in the present use of these archives. It emphasised the role of historical analysis in the ongoing definition of an urban project, exploring how the reproduction of a document interacts with the transformations of architectural or urban spaces. By visualising a system of interactions, the lisuel layer provides room for critical analysis of the urban project.

To illustrate the possibility of constructing a thought pattern around the notion of lisuel, we started with the history of the Plan Industriel as a specific cartographic document which dates to 1910 . Its description led us to gather a series of maps produced by the same consortium. The lisuel layer features information that was not visible at first glance on the Plan Industriel but that was made readable by consulting archives. The representation of the lisuel is constructed as a thought pattern that reveals the process through which the sources were consulted. It acts as a visual translation of a reading of the historical sources that provide information on the urban history of Brussels. The representation of the lisuel layer has been explored using three methods. The first, extraction, started with a deep reading of the Plan Industriel as a fragmentary image envisioning the past with very detailed etched vignettes. Extraction helps visualise the production of urban space by focusing on featured situations. The second method, classification, organised these featured situations into themes linked to urban production chains, revealing the economic regime that conditioned forms of living in the city. The third method, juxtaposition, linked the first two methods to a specific spatial story that revealed the relationship be- tween forms of manufacturing companies and the production of urban living conditions. Applying juxtaposition to Louis De Waele's spatial story showed how this general public works company (which was also a royal contractor) was involved in the configuration of a system of social relationships and contributed to the implementation of the Besme plan.

Comparing the Plan Industriel (as a document without a projective aim) to the Besme plan and the IGN map produced by the official cartographic establishment allowed for assessing its value as an image representing the economic regime of urban production in 1910 Brussels. The contribution of the visual analysis does not concern urban form specifically as a spatial form but as an imagery that supports a strategic discourse. The workers' housing estates, industrial district, and green boulevards projected by Besme, supported by King Leopold II, and built by local entrepreneurs are featured situations displayed on the Plan Industriel. It is also noticeable that the plan does not place any emphasis on Art Nouveau architecture, which nevertheless marked the city's image.

The World's Fair shows a specific form of interaction between entrepreneurs and urban project actors. The World's Fair Company was indeed a powerful actor in an all-inclusive urban project. Entrepreneurships influence the way in which other entrepreneurs as well as architects, craftsmen, and political figures generate patterns of collaboration and cooperation. The forms of manufacturing companies mentioned with regard to the analysis of De Waele's company show that the more a local economic player becomes globalised, the less significant is its spatial footprint on the local space. The study of the history of De Waele's company also underlined its belonging to a Belgian movement that brought together craftsmen influenced by the arts and crafts. Focusing on the arts and crafts movement led to distinguishing two patterns of circularity: an all-inclusive cluster on one hand and a cooperative network of craftsmen disseminated through the urban space on the other hand.

More than being a cartographic investigation, this work clarifies an understanding of the challenges we face today in envisioning Brussels as a productive city. It argues for a critical stance regarding the tools for visualising a palimpsest-based urban project.

\section{Acknowledgments}

This work was supported by the Brussels Capital Region through the European Regional Development Fund.

\section{Conflict of Interests}

The author declares no conflicts of interest.

\section{References}

Atelier de Recherche et d'Action Urbaine. (1984). Bruxelles vu par ses habitants: Ou quinze années d'action ur- 
baine [Brussels as seen by its inhabitants: Or fifteen years of urban action]. Brussels: Commission française de la culture de l'agglomération de Bruxelles.

Arnaud, J.-L. (2008). Analyse spatiale, cartographie et histoire urbaine [Spatial analysis, cartography and urban history]. Marseille: Parenthèses.

Bertels, I., Deneweth, H., Horemans, B., \& Van De Voorde, S. (2016). Pour une historiographie de l'entrepreneur du bâtiment (1400-2000) [For a historiography of the building contractor (1400-2000)]. In F. Fleurey, L. Baridon, A. Mastrorilli, R. Mouterde, \& N. Reveyron (Eds.), Les temps de la construction. Processus, acteurs, matériaux [Construction times. Processes, actors, materials] (pp. 1989-1999). Paris: Picard.

Besme, V. (1866). Plan d'ensemble pour l'extension et l'embellissement de l'agglomération bruxelloise [Plan for the extension and beautification of the Brussels conurbation]. Brussels: Établissement géographique.

Corboz, A. (1983). Le territoire comme palimpseste [The land as palimpsest]. Diogène, 121, 14-35.

Corboz, A. (Ed.). (1993). Atlas du territoire genevois. Permanences et modifications cadastrales au XIXè et XXè siècles [Atlas of the Geneva territory. Permanencies and cadastral modifications in the 19th and 20th centuries]. Genève: Département des travaux publics du canton de Genève, Service des monuments et des sites. Chêne-Bourg Genève, Georg Editeur.

Culot, M., \& the Archives d'Architecture Moderne. (Ed.). (1980-1982). Inventaire visuel de l'architecture industrielle à Bruxelles [Visual inventory of industrial architecture in Brussels]. Brussels: Ministère de la communauté française.

Danckaert, L. (1989). Bruxelles. Cinq siècles de cartographie [Brussels. Five centuries of cartography]. Tielt: Lannoo.

De Beule, M. (Ed.). (2017). Bruxelles, histoire de planifier: Urbanisme aux 19e et 20e siècles [Brussels, history of planning: Urban planning in the 19th and 20th centuries]. Brussels: Mardaga.

Degraeve, M., Dobbels, J., Bertels, I., Deneweth, H., \& Van De Voorde, S. (2018). Spatial management of contractors. An analysis of the industrial sites of the Louis De Waele enterprise in Brussels (1867-1988). In I. Wouters, S. Van De Voorde, I. Bertels, B. Espion, K. De Jonge, \& D. Zastavni (Eds.), Building knowledge, constructing histories (Vol. 1, pp. 527-535). New York, NY: CRC Press.

Dhuicque, E. (1927). Architecture industrielle [Industrial architecture]. L'Émulation, 47, 129-132.
Gullentops, D. (2001). Poétique du lisuel [Poetics of the lisuel]. Paris: Mediterra.

IGN. (1910). Bruxelles [Brussels]. Brussels: Institut cartographique militaire. Retrieved from https://lib. ugent.be/catalog/rug01:001809470

Jaumain, S. (2010). Bruxelles 1910: De l'Exposition universelle à l'Université [Brussels 1910: From the World's Fair to the University]. Brussels: Racine.

Pousin, F. (Ed.). (2005). Figures de la ville et construction des savoirs. Architecture, urbanisme, géographie [Figures of the city and construction of knowledge. Architecture, town planning, geography]. Paris: CNRS éditions.

Rao, V. (2009). Embracing urbanism: The city as archive. New Literary History, 40(2), 371-383. https://doi. org/10.1353/nlh.0.0085

Région de Bruxelles-Capitale. (2019). Inventaire du patrimoine architectural [Inventory of architectural heritage]. Iris Monument. Retrieved from http://www. irismonument.be

Schoonbrodt, R. (2007). Vouloir et dire la ville: Quarante années de participation citoyenne à Bruxelles [To desire and to disclose the city: Fourty years of citizens' participation in Brussels]. Brussels: AAM.

Schroeder-Gudehus, B., \& Rasmussen, A. (1992). Les fastes du progrès: Le guide des expositions universelles 1851-1992 [The splendour of progress: A guide to the world's exhibitions 1851-1992]. Paris: Flammarion.

Söderström, O. (2000). Des images pour agir: Le visuel en urbanisme [Images for action: Visuals in urban planning]. Lausanne: Payot.

Taylor, F. W. (1911). The principles of scientific management. New York, NY: Harper.

Van Damme, S. (2012). Métropoles de papier. Naissance de l'archéologie urbaine à Paris et Londres (XVIle-XXe siècles) [Metropolises of paper. Birth of urban archaeology in Paris and London (17th-20th centuries)]. Paris: Les Belles Lettres.

Verwest, A., Vanderoost, M., \& Xhardez, F. (1910a). Nouveau plan de Bruxelles industriel avec ses suburbains [New map of industrial Brussels with its suburbs]. Brussels: Khiat.

Verwest, A., Vanderoost, M., \& Xhardez, F. (1910b). Nouveau plan de Bruxelles Mondain [New map of Brussels Mondain]. Brussels: Khiat.

Zitouni, B. (2010). Agglomérer. Une anatomie de l'extension bruxelloise (1828-1915) [Agglomerate. An anatomy of the Brussels extension (1828-1915)]. Brussels: VUBPress.

\section{About the Author}

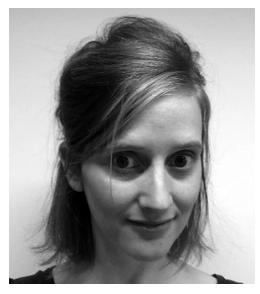

Marine Declève is a PhD candidate at Ecole Polytechnique Fédérale de Lausanne (EPFL, Switzerland) and Metrolab Brussels (UCLouvain and ULB, Belgium). She earned a master's degree in Art History and Archaeology (UCLouvain, 2009) and a master's degree in Urbanism and Strategic Planning (KULeuven and EMU, 2015). She conducts her PhD under the guidance of Elena Cogato Lanza. Through an iconographic and cartographic investigation, her research focuses on the relationship to the city of local manufacturing activities, specifically those that fuelled the building of Brussels and contributed to the transformation of its urban space at different times in its history. 